Vol. 8(30), pp. 1005-1013, 10 August, 2014

DOI: 10.5897/J MPR2014.5505

Artic le Number: AA8AFB146851

ISSN 1996-0875

Copyright (c) 2014

Author(s) retain the copyright of this artic le

http://www.academic joumals.org/J MPR

Journal of Medicinal Plant Research

Full Length Research Paper

\title{
Medicinal plants used in child care in southern Brazil
}

\author{
Angela Erna Rossato ${ }^{1}$, Mariana Borsatto D'Agostin ${ }^{1}$, Jeverson Moreira ${ }^{2}$, Silvia DalBó ${ }^{1}$, \\ Vanilde Citadini-Zanette ${ }^{1}$ and Patrícia de Aguiar Amaral ${ }^{1 *}$ \\ ${ }^{1}$ Laboratory of Medicinal Plants (LaPlaM/ PPGCA), Universidade do Extremo Sul Catarinense (UNESC), \\ Avenida Universitária 1105, Bairro Universitário, 88806-000 Criciúma, SC, Brazil. \\ ${ }^{2}$ Université Paris Descartes, Faculté des Sciences Pharmaceutiques et Biologiques, INSERM U705, 4 Avenue de \\ l'Observatoire, 75006-Paris, France.
}

Received 28 June, 2014; Accepted 7 August, 2014

\begin{abstract}
In many cultures throughout the world, mostly in developing countries, medicinal plants play an important role in the maintenance of people's health. Despite this, some plants can be inherently toxic. People are not generally well-informed about this risk, and the concept that natural means safe prevails. Considering the associated risk of the misuse of medicinal plants, children represent an even more vulnerable group than adults. The main goal of this study is to evaluate the local knowledge of medicinal plants related to child care by mothers and care takers in a district of Criciúma, Southern Brazil. An ethnobotanical household survey was carried out with $\mathbf{4 2}$ mothers or care takers through open interviews, and botanical samples of the plants they used were gathered. The information collected about traditional knowledge was compared with references cited in Normative Instruction $n^{\circ} 5$ journal, and other scientific literature in order to evaluate similarities and differences. A total of 18 plant species were mentioned. Information on $\mathbf{8 3} \%$ of cited plants were found in the scientific references. $51 \%$ of therapeutic uses matched the literature guidelines. There was an absence of indications and restrictions for use with children for $34 \%$ of mentioned plants. The use of medicinal plants can be considered an important element in the maintenance of local knowledge and culture. This practice also represents an affordable therapeutic option, in communities where poverty and a lack of access to modern medicine are prominent factors. Just like other medicines, medicinal plants may have side effects however, and administration to children should be performed with careful attention.
\end{abstract}

Key words: Ethnobotany, local plant knowledge, medicinal plants, children.

\section{INTRODUCTION}

Throughout human history medicinal plants have been used in health recovery, and have evolved from simple household preparations to complex artificial forms (Lorenzi and Matos, 2008). Despite the growing development of public health policies around the globe, data from the World Health Organization (WHO, 2004a) estimates that between 1.3 and 2.1 billion people live without access to essential medicines, and that in many developing countries traditional medicine represents a key option for primary care for 70 to $95 \%$ of the population 
(WHO, 2011). In 2006 the Brazilian Ministry of Health (MS), through the National Health Surveillance Agency (ANVISA) published the No. 5.813 Decree in order to ensure the safety, efficacy and quality of medicinal plants and herbal medicines, and promote their rational use by the Brazilian population. (BRAZIL, 2006a). Normative Instruction (NI) publication (No. 5 March $31^{\text {st }} 2010$ (BRAZIL, 2010) lists references used to evaluate the safety and efficacy of medicinal plants. This publication was used as a guideline to evaluate the local uses of medicinal plants cited in our research. These guidelines are not, however, applicable to the use of medicinal plants with children.

Even without specific Brazilian legislation for the use of medicinal plants in children, the ancient practice is still present among young mothers. The growing trend towards a more natural way of life has led to the increased use of medicinal plants in Brazilian society over recent decades, and consequently the use of phytopharmaceutical products augments modern medicine. In this setting, medicinal plants are generally considered low risk (Mengues et al., 2001), but this is a misconception because some plants can present adverse effects or even be intrinsically toxic. Furthermore, the misguided use of the wrong species in a traditional medicine, or the potential contamination of plant material by toxic substances such as metals and pesticides have the potential to increase the risks associated with medicinal plant use (WHO, 2004b). Given the growing use of herbal medicines and medicinal plants in Brazil and around the world, it is important to predict the inherent risks linked to the use of some plant species, since pharmacological effects can be noxious to a user's health (WHO, 2002a). The Normative Instruction (NI) publication $\left(\mathrm{n}^{\circ} 5\right.$, March $31^{\text {st }}$ 2010 (BRAZIL, 2010)) lists references for use in evaluating the safety and efficacy of medicinally-relevant plants.

This publication was used as a guideline when evaluating the local uses of medicinal plants cited in our survey. Higher risks are clearly associated with the use of plants in children. Numerous physiological differences between children and adults, such as protein binding capacity and immature function of renal and hepatic systems, can be responsible for overdoses and other toxic events (Ginsberg et al., 2004; Rang et al., 2007). Brazilian law does not advocate the use of herbal medicines with children, but it is an ancient practice used by many mothers, influenced by the popular use of certain medicinal species. Considering the hypothesis of a higher risk associated with plants used in child care, and the importance of monitoring the safety of medicinal plants within traditional medicine systems, this survey aims to evaluate the knowledge of medicinal plants used in child care by mothers and care takers in a district of Criciúma, Santa Catarina State, Southern Brazil, and to compare the collected information with references cited in Normative Instruction (NI) no. 5 (BRAZIL, 2010) and other scientific literature, so as to analyse similarities and differences.

\section{METHODS AND MATERIALS}

\section{Study area and group}

Criciúma was founded at the end of the 19th century during the cycle of European immigration to Brazil. The first immigrant families were Italians coming from regions of Venice and Treviso. During the 1920s, the city experienced social and economic change due to coal exploitation. Nowadays, the estimated population is 202,395 habitants, and the main industrial activities include ceramics, coal extraction, textiles, metallurgy and plastic (IBGE, 2013). The study was conducted in São Roque, a district in the south of Criciúma (Santa Catarina, southern Brazil). São Roque is located at latitude $28^{\circ} 41^{\prime} 45.63^{\prime \prime} \mathrm{S}$ and longitude $49^{\circ} 23^{\prime} 57.62 " \mathrm{~W}$, approximately 4 kilometres from Criciúma's downtown (Figure 1). It has a population of 748 inhabitants divided into 142 households. The area consists of a moist tropical forest zone fragmented by agricultural fields (IBGE, 2004). Both the information and the call for participation were made through preliminary visits to district families. Interviews were conducted with mothers and care takers living in the district and who agreed to take part in the study, giving informed consent.

\section{Ethnobotanical study}

The study was carried out in March and April 2010 in accord with Resolution $n^{\circ} 196 / 96$ (National Health Council). Data collection consisted basically of interviews using a questionnaire designed by Martin (1995) with modifications. The research was approved by the Ethic Committee of UNESC (Universidade do Extremo Sul Catarinense) under Article $n^{\circ} 95 / 2010$. The questionnaire was designed to be anonymous, confidential, and to collect information on local knowledge of the plants used with children. Due to possible differences in the literacy levels of interviewees, it was decided that the questions would be asked verbally and that the answers would be filled in on the questionnaire by the interviewers. The interviews were carried out in participant's homes and lasted as long as the participant found necessary.

\section{Botanical material}

During the interviews, medicinal plants cited in the survey and available near the interview sites were collected in order to conduct plant identification. Some interviewees reported using plant material purchased at local herbalists and pharmacies. In this case, when plant material was in the appropriate condition a sample was collected for later plant identification. When this was not possible, the plant nomenclature presented on the packaging was assessed. In this case, only plants produced by registered industries (in agencia Nacional de Vigilância Sanitária - ANVISA) were considered. Plant specimens were identified by botanical specialist Dr Vanilde Citadini Zanette, and sample specimens were deposited at the Herbarium Padre Dr. Raulino Reitz of UNESC-Criciúma.

\section{Data analysis}

In order to evaluate the knowledge of medicinal plants used in child care by mothers and care takers from the São Roque district, the information collected was compared with references cited in the $\mathrm{NI}$ publication. 


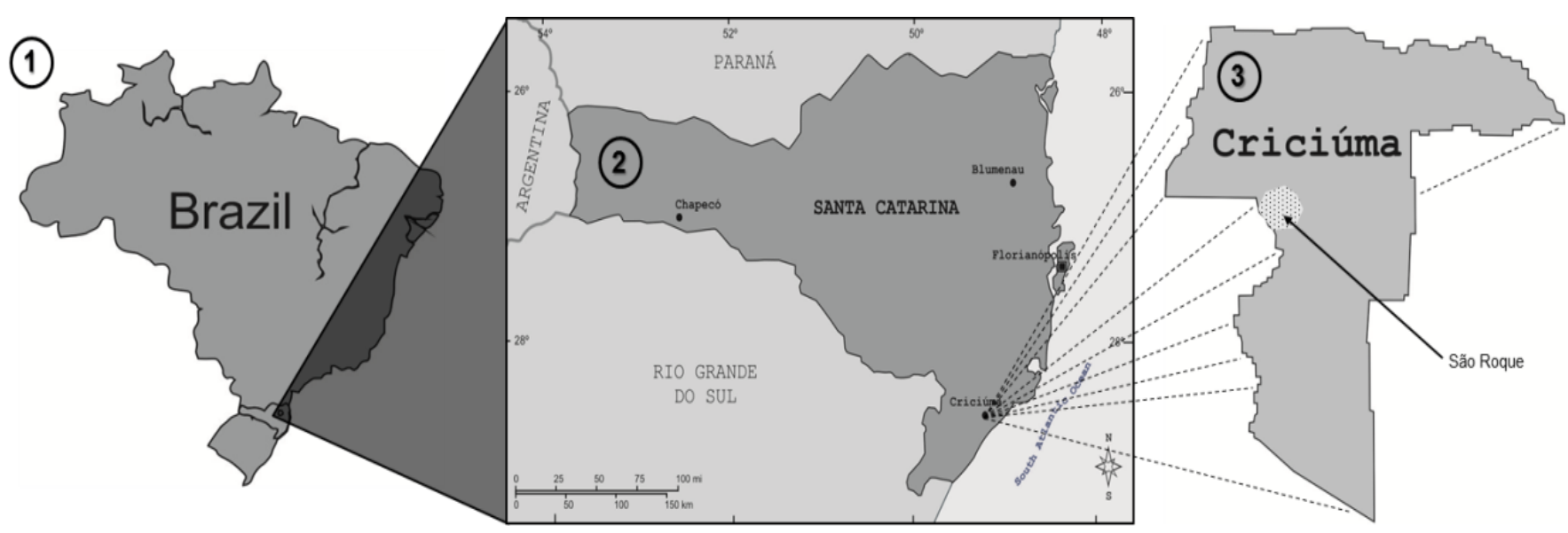

Figure 1. Location of the São Roque district. 1-Brazil; 2-Santa Catarina State; 3-Criciúma; the arrow and the light-dotted area show the São Roque district.

Table 1. Study demographic data.

\begin{tabular}{lc}
\hline Participant educational levels & $\%$ \\
\hline Primary school & 7.2 \\
Secondary school & 38.0 \\
High school & 50.0 \\
University & 4.8 \\
\hline
\end{tabular}

Table 2. Children's age in years.

\begin{tabular}{lc}
\hline $\mathbf{( n = 5 2 )}$ & $\%$ \\
\hline 0 to 1 & 17.3 \\
2 to 5 & 40.4 \\
6 to 9 & 15.4 \\
10 to 12 & 26.9 \\
\hline
\end{tabular}

\section{RESULTS}

All families residing in San Roque were contacted and households with children, mothers or carers were invited to participate in the research. During an initial interview in São Roque district, 50 participants were found to be eligible, but only 42 agreed to take part in the study. Participant ages ranged from 16 to 52 years old and education levels varied from some literacy to university degrees. Data analysis also showed diversity in the participant's socio-professional occupations. A total of 52 children were living in the 42 households visited and $40.4 \%(n=21)$ of these children were 2 to 5 years old. Their schooling and total distribution by age group is shown in Table 1 and 2, respectively. All interviewees reported some knowledge of the use of at least one medicinal plant for child care. Participants were asked about the origin of their knowledge and the majority reported that the information was passed down from their parents, grandparents, elderly people or friends, through oral communication. Few interviewees reported knowledge being obtained using pertinent literature or through the Catholic Church's Health Pastoral (CCHP) informers. Concerning the use of plants with their children, $92.8 \%$ $(n=39)$ of participants reported such use at least once. The other $7.2 \%(n=3)$ declared the non-use of plants due to children's reluctance towards infusions or decoctions and also due to preferences for synthetic medicines which were perceived as more effective. Of the number of interviewees who reported using medicinal plants with children, 38\% $(n=16)$ described their association with synthetic drugs, and from this total, only $45.2 \%(n=19)$ acquainted children's physician about this association. Moreover, $90.4 \% \quad(n=38)$ of interviewees had never received any instructions from health professionals concerning the use of medicinal plants in children's care. Table 3, shows plants used by participants, including their botanical and vernacular name, the plant parts commonly used, their preparation, traditional use and references corroborating traditional use in adults and in children. Matricaria chamomilla L. (Asteraceae), Pimpinella anisum (Apiaceae), Mentha piperita (Lamiaceae) and Melissa officinalis L. (Lamiaceae) were the most frequently cited species (data not shown).

\section{DISCUSSION}

According to the World Health Organisation (WHO, 2002a), traditional medicine, especially herbal medicine, is widely used around the world. In South America, medicinal plant use is linked to historical circumstances, cultural beliefs and socioeconomic factors. The research participants mostly consisted of people who had attended 
Table 3. Plants used in child care at São Roque district.

\begin{tabular}{|c|c|c|c|c|c|c|c|}
\hline \multirow{2}{*}{$\begin{array}{l}\text { Botanical name } \\
\text { (Voucher specimen no.) }\end{array}$} & \multirow{2}{*}{$\begin{array}{l}\text { Botanical } \\
\text { family }\end{array}$} & \multirow{2}{*}{ Vernacular name } & \multirow{2}{*}{$\begin{array}{l}\text { Plant } \\
\text { part(s) } \\
\text { used }\end{array}$} & \multirow{2}{*}{ Preparation } & \multirow{2}{*}{$\begin{array}{l}\text { Claimed } \\
\text { medicinal use }\end{array}$} & \multicolumn{2}{|c|}{ References corroborating for claimed medicinal use } \\
\hline & & & & & & In adults & In children \\
\hline $\begin{array}{l}\text { Achyrocline satureioides (Lam) DC. } \\
\text { (CRI 4536) }\end{array}$ & Asteraceae & Marcela do Campo & Lv & Infusion & Stomach ache & Lorenzi and Matos (2008) & - \\
\hline $\begin{array}{l}\text { Camellia sinensis (L.) Kuntze }{ }^{1} \\
\text { Citrus aurantium L. (CRI 4503) }\end{array}$ & Rutaceae & Laranjeira & Lv & $\begin{array}{l}\text { Infusion, } \\
\text { decoction }\end{array}$ & $\begin{array}{l}\text { Cold, colic, cough, } \\
\text { jaundice }\end{array}$ & $\begin{array}{l}\text { Schilcher (1997), Blumenthal et al. (2000), } \\
\text { Lorenzi and Matos (2008) }\end{array}$ & $\begin{array}{l}\text { Lorenzi and } \\
\text { Matos (2008) }\end{array}$ \\
\hline Cunila microcephala Benth. (CRI 7620) & Lamiaceae & Poejo & LV & Infusion & - & - & - \\
\hline $\begin{array}{l}\text { Cymbopogon citratus (DC.) } \\
\text { Stapf (CRI 2471) }\end{array}$ & Poaceae & Cana-cidreira & Lv & $\begin{array}{l}\text { Infusion, } \\
\text { decoction }\end{array}$ & Cold, anxiety & $\begin{array}{l}\text { Blumenthal et al. (2000), } \\
\text { Lorenzi and Matos (2008) }\end{array}$ & - \\
\hline $\begin{array}{l}\text { Dysphania ambrosioides (L) } \\
\text { Mosyakin and Clemants (CRI 6133) }\end{array}$ & Amaranthaceae & Erva-de-Santa-Maria & Lv & $\begin{array}{l}\text { Infusion, } \\
\text { decoction }\end{array}$ & Vermifuge & $\begin{array}{l}\text { Brasil (2006c), } \\
\text { Lorenzi and Matos (2008) } \\
\end{array}$ & Tramil (1995) \\
\hline Lavandula angustifolia Mill. ${ }^{1}$ & Lamiaceae & Alfazema & Lv & $\begin{array}{l}\text { Infusion, } \\
\text { decoction }\end{array}$ & Colic, cold & $\begin{array}{l}\text { Blumenthal et al. (2000), WHO (2007; 2009), } \\
\text { Lorenzi and Matos (2008) }\end{array}$ & - \\
\hline Lippia alba (Mill.) N. E. Br. (CRI 10005) & Verbenaceae & Sálvia-do-Rio-Grande & Lv & Decoction & Cold & - & - \\
\hline Lippia sidoides Cham. ${ }^{1}$ & Verbenaceae & Alecrim-pimenta & Lv & Decoction & Anxiety & - & - \\
\hline $\begin{array}{l}\text { Matricaria chamomilla L. } \\
\text { Rauschert (CRI 8988) }\end{array}$ & Asteraceae & Camomila & $\mathrm{F}$ & $\begin{array}{l}\text { Infusion, } \\
\text { decoction }\end{array}$ & $\begin{array}{l}\text { Anxiety, colic, nausea, fever, } \\
\text { general pain, constipation }\end{array}$ & $\begin{array}{l}\text { Newall et al. (1996), } \\
\text { Schilcher (1997) }\end{array}$ & $\begin{array}{l}\text { Lorenzi and } \\
\text { Matos (2008) }\end{array}$ \\
\hline Medicago sativa L. ${ }^{1}$ & Fabaceae & Alfafa & Lv & Decoction & Pneumonia & - & - \\
\hline Melissa officinalis L. ${ }^{1}$ (CRI 10167) & Lamiaceae & Evva-cidreira & Lv & $\begin{array}{l}\text { Infusion, } \\
\text { decoction }\end{array}$ & Anxiety, cold, colic & $\begin{array}{l}\text { Schilcher (1997), WHO (1999), Blumenthal et } \\
\text { al. (2000), Schulz et al. (2000), ESCOP } \\
\text { (2003), WHO (2002b) }\end{array}$ & - \\
\hline $\begin{array}{l}\text { Mikania laevigata Sch. Bip. ex Baker } \\
\text { (CRI 7601) }\end{array}$ & Astearaceae & Guaco & Lv & decoction & Cold & - & - \\
\hline $\begin{array}{l}\text { Ocimum carnosum (Spreng.) } \\
\text { Link and Otto ex Benth. (CRI 10165) }\end{array}$ & Lamiaceae & $\begin{array}{l}\text { Alfavaca-anisadal } \\
\text { Alfavaca do Campo } \\
\end{array}$ & $\mathrm{Fr}$ & $\begin{array}{l}\text { Infusion, } \\
\text { decoction }\end{array}$ & $\begin{array}{l}\text { Colic, anxiety, fever, } \\
\text { cough, general pain }\end{array}$ & Lorenzi and Matos (2008) & - \\
\hline Pimpinella anisum L. (CRI 4551) & Apiaceae & Eva-doce & $\mathrm{Fr}$ & $\begin{array}{l}\text { Infusion, } \\
\text { decoction }\end{array}$ & $\begin{array}{l}\text { Colic, cough, fever, } \\
\text { anxiety, general pain }\end{array}$ & Newall et al. (1996) & - \\
\hline Psidium guajava L. (CRI 1417) & Myrtaceae & Goiabeira & Lv & Decoction & Diarrhoea & Matos (2002) & - \\
\hline Tillandsia stricta Sol. ex Sims (CRI 8082) & Bromeliaceae & Bromélia & Lv & Decoction & Jaundice & - & - \\
\hline
\end{tabular}

Plant part (s) used: Lv-leaves, Fl-flower, Fr-fruit; ${ }^{1}$-Plant material purchased at a pharmacy or herbalist, no voucher available. 
attended high school or secondary school. This data is similar to that described by IPEA (2013) noting the municipality of Criciúma as a range of educational human development. According to the IPEA (2013), the fastest growing city in absolute terms was education, and this is reflected in the district of São Roque. According to the literature, cultural and educational aspects influence the selection and use of medicinal plants (Arnous et al., 2005). In developed countries, the use of herbal or other complementary therapies is prevalent, and in recent years, this has also been seen in Brazil (Brasileiro et al., 2008). The survey of São Roque households revealed that leaves are the plant parts mostly used (94.4\%) in medicinal preparations. This preference can be explained by the fact that leaves are generally available throughout the year and in subtropical regions can be collected without inhibiting plant growth and reproduction (Franco and Barros, 2006). Decoctions (63\%), followed by infusions (37\%) were the modes of preparation most reported during the interviews. Medicinal preparations such as infusion and decoction are commonly used by people due to easy preparing process. This kind of medicinal preparation contributes to body water balance and consequently to body temperature homeostasis and toxin depuration (Simões, 2007).

In the São Roque district, local knowledge and practice in plant use is orally transmitted from generation to generation and, less frequently, through written records. Oral transmission is generally the predominant way to disseminate traditional knowledge, but nowadays the accelerated process of modernisation is a threat to this teaching process. The fact that some interviewees reported keeping information on medicinal plants through written records is important, in that it allows the preservation of local traditions and makes the process of knowledge sharing easier. The availability of this data also can be connected with a better understanding of benefits and risks associated with the practice of traditional medicine (Leonti, 2011; WHO, 2011). Few participants $(n=4,9.5 \%)$ reported preferring conventional drugs to the use of medicinal plants with their children. According to participants, conventional drugs are more effective, since the therapeutic effects can be seen faster during the treatment. This could be explained by the fact that therapeutic effects from herbal medicines and medicinal plants treatment are based on the synergistic and additive effects of a vast array of chemical constituents, with an efficacy that can be better seen only two or three weeks after the first administration (Barnes et al., 2007; Schulz et al., 2000). Several studies point to the use of medicinal plants as a therapy form for several populations. Some of the interviewees use medicinal plants with conventional drugs to treat children's ailments without notifying their children's physician of the practice. This lapse is probably not a deliberate act, but because plants contain mixtures of bioactive compounds, precaution must be taken in mixing herbal components and conventional medicines. Medicinal plants and conventional drug combinations are not recommended, simply because plants can interfere with drug pharmacokinetics (Griffin and D'Arcy, 1997). The risk of herb-drug interactions is exemplified in studies with garlic. Results have shown that bioactive compounds from garlic (Allium sativum; popularly known as Alho) in a dose-dependent manner could exert anticoagulant effects and affect haemostatic balance (Chan et al., 2007; Steiner and Li, 2001). In this context, patients using warfarin, for example, should be aware of the increased risk of bleeding associated with excessive garlic ingestion (Alexandre et al., 2008; Chavez et al., 2006). Analysing São Roque's survey, we could see that only a fraction of interviewees $(n=5,11.9 \%)$ reported receiving information on medicinal plants directly from a health professional. Considering the risks associated with the use of medicinal plant-drug combinations, the advice of health professionals is essential for safety in medicinal plant use since they are able to correlate diverse areas of knowledge and thus promote rational use, and enable the use of selected plants in a science-based approach (Barnes et al., 2007; Oliveira et al., 2012). Health pro-fessionals should be encouraged to seek training in this area of knowledge for the purpose of educating the public in the use of medicinal plants.

Research showed that some interviewees, in some instances, obtained information about medicinal plants used in child care from informers of the Catholic Church's Health Pastoral. CCHP informers represent a source of traditional knowledge transmission in southern Brazil (Neumann et al., 1999). This can be explained by looking back in time, when Jesuit missionaries came to help colonise Latin America. Their ability to collect the appropriate information and natural knowledge from indigenous people led the Catholic Church to dispense a wide range of traditional knowledge, placing this organisation at the centre of local knowledge transmission (Harris, 2005; Murray et al., 2011). Even if, historically, traditional medicines are used extensively all over the globe, in many countries the non-existence of regulated use or lack of access to accurate information leads to difficulties in the recognition and validation of traditional practices. Consequently health professionals tend to avoid the use of traditional medicines (WHO, 2000, 2011). Brazil has recently published new public policies specifically related to medicinal plants and traditional medicines so as to regulate, but also promote and encourage the correct use of herbal medicines (BRAZIL, 2006a, 2006b; Carvalho et al., 2010; WHO, 2011). These policies include the previously cited NI (BRAZIL, 2010), which lists the references required to evaluate the safety and efficacy of medicinal plants. This publication was used as guideline to evaluate the local uses of medicinal plants cited in our research. Of the total number of species cited by interviewees in this study, 83\% were present in the references cited in the $\mathrm{NI}$ no. 5 and in other scientific literature, and 
$55 \%$ of the species had their claimed medicinal use in child care indicated in the consulted references. The plant parts used in the traditional preparations were in accordance with the references for $93 \%$ of plants. Of the traditional preparations cited by participants, $36 \%$ of species had no compatibility of preparation method when compared with the literature. It is important to understand that plants contain chemical compounds, and that the efficacy of medicinal plants in the treatment of ailments can only be achieved if the correct and validated traditional use is undertaken. Selecting the species to be used, as well as the adequate plant part and preparation method, are thus important processes preceding the therapy. The extraction of bioactive compounds from plants depends mainly on the preparation method; and so the lack of correlation between preparation methods used by interviewees and those described in literature for at least $1 / 3$ of the cited species can be a limiting factor to the therapeutic effects of these preparations (Bast et al., 2002).

Our data revealed that $51 \%$ of the therapeutic purposes indicated by participants were in accordance with scientific literature. Clinically-controlled studies, as well as the long history of traditional use for a plant can represent a good level of safety and efficacy. On the other hand, the use of a herb based only on personal experience can be seen as unscientific and therefore must be avoided (Barret, 2004; Pontes et al., 2006). Only 34\% of plants reported here had corroborating references for their specific medicinal use with children. As previously mentioned, physiological particularities present in children, mostly in neonates and infants, must be taken into account before using medicinal plants or conventional drugs. Changes in the protein binding capacity as well as immaturity of renal and hepatic systems can be linked to a higher incidence of toxic events and even the death of children (Anderson, 2010; Clayton and Stock, 2006; Ginsberg et al., 2004; Rang et al., 2007). According to NI $\mathrm{n}^{\circ} 5$ references, some of plants cited by participants should not be used in child care to avoid possible side effects and other damaging events. By way of example, the intake of a chamomile (Matricaria chamomilla L.; popularly known as Camomila) infusion may precipitate an anaphylactic reaction and bronchial asthma, as reported in an 8 year old male (Subiza et al., 1989). Thus, its use should be avoided in children and people with a history of allergy (PDR, 2007; Subiza et al., 1990). However, Matricaria chamomilla L., is associated with several references reporting its anti-inflammatory effects, and its use in the treatment of gastric ailments and mild insomnia. Thus, it is established that the claimed use reported by participants seems to be supported (PDR, 2007; WHO, 1999). Participants reported the use of a Camellia sinensis (popularly known as chá preto) (Theaceae) decoction or infusion to treat colic and anxiety problems in their children. It can be assumed that the warm sensation induced by the ingestion of a hot cup of infusion could have some effect on the colic pain, as simple abdominal massage. On the other hand, the phytochemical composition of $C$. sinensis, mostly the presence of caffeine, is certainly not indicated for the treatment of anxious states. Caffeine has a central stimulating effect and its intake can lead to symptoms such as restlessness, irritability and sleeplessness (PDR, 2007). Paradoxically, recent studies show that Ltheanine, an amino acid also found in $C$. sinensis, exerts the opposite pharmacology and could be responsible for the anxiolytic effect reported by participants (Wise et al., 2012; Yoto et al., 2012). Daily ingestion of a C. sinensis decoction, by children whose diet does not include sources of haeme-derived iron, can also induce changes in iron absorption and thus lead to the development of microcytic anaemia. Its consumption should thus be limited in these populations, or food intake should be adjusted to include haeme-derived iron sources (Merhav et al., 1985; PDR, 2007; Srichairatanakool et al., 2006; Temme and Van Hoydonck, 2002). Concerning Mentha piperita (popularly known as hortelã), participants reported the use of an infusion/decoction from plant leaves to treat cough and cold conditions, as well as a vermifuge medicine. The treatment of common cold symptoms by $M$. piperita is well described in pharmacopeias and traditional systems of medicine (Blumenthal et al., 2000; WHO, 2002b), whereas its vermifuge action is poorly documented. Recent in vitro studies demonstrate that $M$. piperita essential oil is active against Echinococcus granulosus (Maggiore et al., 2012). In addition, some precautions must be taken when using M. piperita in children, mostly preparations containing the essential oil, that should not be topically used (in the nasal area) in infants due to the risk of glottal or bronchial spam induced by possible hypersensitivity reactions ( Vanaclocha and Cañigueral, 2003; PDR, 2007).

Dysphania ambrosioides (L.) Mosyakin and Clemants (popularly known as erva de Santa Maria), and its chief constituent ascaridole, possess anthelmintic properties well described in literature (BRAZIL, 2006c; PDR, 2007), nevertheless the toxicity associated with this plant shows that it should be used cautiously, with children. In vitro genotoxic effects of the $D$. ambrosioides (L.) decoction and infusion have been recently reported (Gadano et al., 2002), furthermore, central nervous system disorders can also occur even with a therapeutic dosage of this plant. Taken together, these findings reveal that risks and benefits must be seriously balanced before using $D$. ambrosioides (L.) preparations (PDR, 2007; Tôrres et al., 2005). Approved indications of Melissa officinalis L. (popularly known as Erva-cidreira) include nervousness and insomnia, both symptoms associated with anxiety disorders, and also as a carminative for gastrointestinal disorders (PDR, 2007; WHO, 2002b). However, its use for treating cold conditions is not corroborated by scientific references. Concerning Achyrocline satureioides (Lam.) (popularlyknown asmarcela do campo) 
a large number of studies show various properties for this plant, such as anti-inflammatory (Barioni et al., 2013; De Souza et al., 2007) and as an antioxidant (Arredondo et al., 2004; Desmarchelier et al., 1998; Polydoro et al., 2004), but few references report its direct effect on the gastrointestinal system for treating stomach aches (Simoes et al., 1988). On the other hand, studies have shown that an aqueous extract from the plant is devoid of acute toxicity, thus even if further data was necessary to support its popular use, the administration of an $A$. satureioides infusion in children can be considered riskfree (Rivera et al., 2004).

Citrus aurantium L. (popularly known as laranjeira) preparations present no health hazards or side effects when used in therapeutic doses and the plant possesses experimental data corroborating its use to treat dyspeptic complaints (PDR, 2007), however plant peel oil can elevate UV-sensitivity in light-skinned children through the phototoxic effect of furocoumarins. Concerning, recent experimental data indirectly supports its claimed use in jaundice, as reported herein. Citrus flavonoids seem to inhibit hyperlipidaemia and hepatic adiposity through a direct action on lipid metabolism, thus having a protective action in liver antioxidant systems and reducing lipid formation (Lin et al., 2011; Nichols et al., 2011; Park et al., 2013). Participants reported using Lavandula angustifolia Mill. (popularly known as alfazema) to treat gastrointestinal and respiratory issues in children, however experimental data does not support its use in this population. Infusion and decoction from the plant should be only administered under the supervision of a health professional (WHO, 2007). Pimpinella anisum (popularly known as erva doce) does not have clinical data validating its use with children or adults. On the other hand, it is widely used in traditional medicine systems and culinary preparations. Adverse reactions in infants have been reported and include allergic reactions to contact with the plant oil. As such, its use is contraindicated in children under 12 years old (WHO, 2007). Regarding Cunila microcephala (popularly known as poejo), Lippia alba (popularly known as salvia-do-riogrande, Lippia sidoides (popularly known as alecrim pimenta), Medicago sativa (popularly known as alfafa), Mikania laevigata (popularly known as guaco), Ocimum selloi (popularly known as alfavaca-anisada), Psidium guajava (popularly known as goiabeira) and Tillandsia stricta (popularly known as bromélia), the scientific data currently available neither corroborates the claimed medicinal uses reported herein nor predict plant safety and efficacy in children care. Parents and carers should therefore work in conjunction with health professionals in order to choose alternative traditional medicine preparations devoid of directly or indirectly harmful effects (Frenkel and Borkan, 2003; Oliveira et al., 2012).

\section{CONCLUSION}

Mothers and carers from the São Roque district were found to use a total of 18 plants belonging to 11 distinct botanical families for child care. The plants most cited were Matricaria chamomilla L., Pimpinella anisum, Mentha piperita and Melissa officinalis L. Decoction and infusion were the preferred preparation modes and the leaves were the plant parts prevalently used. Data revealed that $92.8 \%$ of respondents used plants for treating children's illnesses. Only one-third of plants cited by participants possessed references corroborating their use in child care. On the other hand, this data emphasises the importance of preserving and validating local knowledge and traditional practices on a risk-devoid basis. Even if carers seem to have access to, and do not reject conventional medicine, their cultural values and personal beliefs are important factors in the use of local herbal medicines. The need to promote their children's health in an independent way can be proposed as an explanation for these local habits. Further studies are necessary to better understand local plant knowledge in order to prove its efficacy and safety in children care. Mothers and carers from the district should be assisted in choosing plants with demonstrated validity in child care. Public education measures are also necessary to fight the idea that 'natural' means 'safe' and the dangerous assumption that concomitant use of plants and conventional medicines is devoid of any risk.

\section{ACKNOWLEDGEMENTS}

We are grateful to Conselho Nacional de Desenvolvimento Cientifico e Tecnologico (CNPq), Fundação de Amparo à pesquisa de Santa Catarina (FAPESC) and Universidade do Extremo Sul Catarinense (UNESC) for their financial support. We would also like to thank the community of São Roque who made this study possible.

\section{Conflict of interests}

The author(s) have not declared any conflict of interests.

\section{REFERENCES}

Alexandre RF, Bagatini F, Simoes CMO (2008). Potential interactions between drugs and valerian or garlic herbal medicines. Rev. Bras. Farmacogn. 18:455-463.

Anderson GD (2010). Developmental pharmacokinetics. Semin. Pediatr. Neurol. 17:208-213.

Arnous AH, Santos AS, Beinner RPC (2005). Plantas medicinais de uso caseiro-conhecimento popular e interesse por cultivo comunitário. Espaç.Saúde. 6(2):1-6.

Arredondo MF, Blasina F, Echeverry C, Morquio A, Ferreira M, AbinCarriquiry JA, Lafon L, Dajas F (2004). Cytoprotection by Achyrocline satureioides (Lam) D.C. and some of its main flavonoids against oxidative stress. J. Ethnopharmacol. 91:13-20.

Barioni ED, Santin JR, Machado ID, Rodrigues SF, Ferraz-de-Paula V, Wagner TM, Cogliati B, Correa Dos Santos M, Machado MS, Andrade SF, Niero R, Farsky SH (2013). Achyrocline satureioides 
(Lam.) D.C. Hydroalcoholic Extract Inhibits Neutrophil Functions Related to Innate Host Defense. Evid. Based Complement. Altern. Med. 1-12.

Barnes J, Anderson LA, Phillipson JD (2007). Herbal Medicines, 3rd ed. Pharmaceutical Press, London, UK.

Barret M (2004). The Handbook of Clinically Tested Herbal Remedies. Haworth Herbal Press, New York, US.

Bast A, Chandler RF, Choy PC, Delmulle LM, Gruenwald J, Halkes SBA, Keller K, Koeman JH, Peters P, Przyrembel H, de Ree EM, Renwick AG, Vermeer ITM (2002). Botanical health products, positioning and requirements for effective and safe use. Environ. Toxicol. Pharmacol. 12:195-211.

Blumenthal M, Goldberg A, Brinckmann J (2000). Herbal Medicine: Expanded Comission E Monographs, 1st ed. Integrative Medicine Communications, Newton, US.

Brasileiro BG, Pizziolo VR, Matos DS, Germano AM, Jama CMA (2008). Plantas medicinais utilizadas pela população atendida no Programa de Saúde da Família, Governador Valadares, MG, Brasil. Rev. Bras. Ciências Farm. 44(4):629-636.

BRAZIL (2006a). Decree no. 5.813, June 22nd 2006, Aprova a politica Nacional de Plantas Medicinais e Fitoterapicos e da outras providências. Ministry of Health, ANVISA (National Health Surveillance Agency), Brazil.

BRAZIL (2006b). Portaria no. 971, May 3rd 2006. Aprova a Politica Nacional de Praticas Integrativas e Complementares (PNPIC) no Sistema Unico de Saude. Ministry of Health, ANVISA (National Health Surveillance Agency), Brazil.

BRAZIL (2006c). A fitoterapia no SUS e o programa de pesquisa de plantas medicinais da central de medicamentos. Secretariat for science, technology and strategy inputs, Brazil.

BRAZIL (2010). Normative Instruction no. 5, March 31st 2010. Lista de Referências Bibliograficas para avaliação de segurança e eficacia de medicamentos fitoterapicos. Ministry of Health, ANVISA (National Health Surveillance Agency), Brazil.

Chan KC, Yin MC, Chao WJ (2007). Effect of diallyl trisulfide-rich garlic oil on blood coagulation and plasma activity of anticoagulation factors in rats. Food Chem. Toxicol. 45:502-507.

Chavez ML, Jordan MA, Chavez PI (2006). Evidence-based drug-herbal interactions. Life Sci. 78:2146-2157.

Clayton BD, Stock YN (2006). Farmacologia na pratica de enfermagem 13th ed. Elsevier, Rio de Janeiro, BR.

de Carvalho NC, Correa-Angeloni MJ, Leffa DD, Moreira J, Nicolau V, Amaral PA, Rossatto AE, de Andrade VM (2011). Evaluation of the genotoxic and antigenotoxic potential of Melissa officinalis in mice. Genet. Mol. Biol. 34:290-297.

De Souza KC, Bassani VL, Schapoval EE (2007). Influence of excipients and technological process on anti-inflammatory activity of quercetin and Achyrocline satureioides (Lam.) D.C. extracts by oral route. Phytomedicine 14:102-108.

Desmarchelier C, Coussio J, Ciccia G (1998). Antioxidant and free radical scavenging effects in extracts of the medicinal herb Achyrocline satureioides (Lam.) DC. ("marcela"). Braz. J. Med. Biol. Res. 31:1163-1170.

Franco EAP, Barros RFM (2006). Uso e diversidade de plantas medicinais no Quilombo Olho d'Agua dos Pires, Esperantina, Piaui. Rev. Bras. Plantas Medicinais. 8:10.

Frenkel MA, Borkan JM (2003). An approach for integrating complementary-alternative medicine into primary care. Fam. Pract. 20:324-332

Gadano A, Gurni A, Lopez P, Ferraro G, Carballo M (2002). In vitro genotoxic evaluation of the medicinal plant Chenopodium ambrosioides L. J. Ethnopharmacol. 81:11-16.

Ginsberg G, Hattis D, Sonawane B (2004). Incorporating pharmacokinetic differences between children and adults in assessing children's risks to environmental toxicants. Toxicol. Appl. Pharmacol. 198:164-183.

Griffin JP, D'Arcy PF (1997). A Manual of Adverse Drug Interactions, 5th ed. Elsevier Science, Amsterdam, NE.

Harris SJ (2005). Jesuit scientific activity in the overseas missions, 1540-1773. Isis; an international review devoted to the history of science and its cultural influences. 96:71-79.

IBGE (2004). Mapa de Vegetação do Brasil, 3rd ed. IBGE, Brazil.
IBGE (2013). Criciuma Demographic Data - 2013. IBGE.

IPEA - Instituto de Pesquisa Econômica Aplicada (2013). Atlas de desenvolvimento humano do Brasil. Municípios e faixa de desenvolvimento humano.

Leonti M (2011). The future is written: Impact of scripts on the cognition, selection, knowledge and transmission of medicinal plant use and its implications for ethnobotany and ethnopharmacology. J. Ethnopharmacol. 134:542-555.

Lin Y, Vermeer MA, Bos W, Van Buren L, Schuurbiers E, Miret-Catalan S, Trautwein EA (2011). Molecular structures of citrus flavonoids determine their effects on lipid metabolism in HepG2 cells by primarily suppressing apoB secretion. J. Agric. Food Chem. 59: 4496-4503.

Lorenzi H, Matos FJ (2008). Plantas Medicinais no Brasil: nativas e exoticas, 2nd ed. Instituto Plantarum, São Paulo, BR.

Maggiore MA, Albanese AA, Gende LB, Eguaras MJ, Denegri GM, Elissondo MC (2012). Anthelmintic effect of Mentha spp. essential oils on Echinococcus granulosus protoscoleces and metacestodes. Parasitol. Res. 110:1103-1112.

Martin GJ (1995). Ethnobotany: A Methods Manual. Chapman and Hall, London. P 80.

Mengues SS, Mentz LA, Schenkel EP (2001). Uso de plantas medicinais na gravidez. Rev. Bras. Farmacogn. 11:14.

Merhav H, Amitai Y, Palti H, Godfrey S (1985). Tea drinking and microcytic anemia in infants. Am. J. Clin. Nutr. 41:1210-1213.

Murray LR, Garcia J, Munoz-Laboy M, Parker RG (2011). Strange bedfellows: The Catholic Church and Brazilian National AIDS Program in the response to HIVIAIDS in Brazil. Soc. Sci. Med. 72:945-952.

Neumann NA, Victora CG, Halpern R, Guimarães PRV, Cesar JA (1999). Desempenho da Pastoral da Criança na promoção de ações de sobrevivência infantil e na educação em saúde em Criciúma, uma cidade do sul do Brasil. Rev. Panam. Salud Publica. 5:11.

Nichols LA, Jackson DE, Manthey JA, Shukla SD, Holland LJ (2011). Citrus flavonoids repress the mRNA for stearoyl-CoA desaturase, a key enzyme in lipid synthesis and obesity control, in rat primary hepatocytes. Lipids Health Dis. 10:36.

Oliveira SG, de Moura FR, Demarco FF, Nascente PS, Pino FA, Lund RG (2012). An ethnomedicinal survey on phytotherapy with professionals and patients from Basic Care Units in the Brazilian Unified Health System. J. Ethnopharmacol. 140:428-437.

Park HY, Choi HD, Eom H, Choi I (2013). Enzymatic modification enhances the protective activity of citrus flavonoids against alcoholinduced liver disease. Food Chem. 139:231-240.

PDR (2007). Physician Desk Reference for Herbal Medicines. Medical Economics Company, New Jersey, US.

Polydoro M, Souza KC, Andrades ME, Da Silva EG, Bonatto F, Heydrich J, Dal-Pizzol F, Schapoval EE, Bassani VL, Moreira JC (2004). Antioxidant, a pro-oxidant and cytotoxic effects of Achyrocline satureioides extracts. Life Sci. 74:2815-2826.

Pontes RMF, Monteiro OS, Rodrigues MCS (2006). The use of phytotherapy in the care of children assisted in a health center of Distrito Federal. Revista Comunicações em Ciências da Saude. $17: 10$

Rang HP, Dale MM, Ritter JM, Flower R (2007). Rang and Dale's Pharmacology, 6th ed. Churchill Livingstone, New York, US.

Rivera F, Gervaz E, Sere C, Dajas F (2004). Toxicological studies of the aqueous extract from Achyrocline satureioides (Lam.) DC (Marcela). J. Ethnopharmacol. 95:359-362.

Schulz V, Hänsel R, Tyler VE (2000). Rational phytotherapy: a physician guide to herbal medicine, 4 th ed. Springer, Berlin, DE.

Simoes C, Schenkel EP, Bauer L, Langeloh A (1988). Pharmacological investigations on Achyrocline satureioides (Lam.) DC. Compositae. J. Ethnopharmacol. 22:281-293.

Simões CMO (2007). Farmacognosia: da planta ao medicamento, 6th ed. UFRGS, Porto Alegre, BR.

Srichairatanakool S, Ounjaijean S, Thephinlap C, Khansuwan U, Phisalpong C, Fucharoen S (2006). Iron-chelating and free-radical scavenging activities of microwave-processed green tea in iron overload. Hemoglobin 30:311-327.

Steiner M, Li W (2001). Aged garlic extract, a modulator of cardiovascular risk factors: a dose-finding study on the effects of 
AGE on platelet functions. J. Nutr.131:980-984.

Subiza J, Subiza JL, Alonso M, Hinojosa M, Garcia R, Jerez M, Subiza E (1990). Allergic conjunctivitis to chamomile tea. Ann. Allergy $65: 127-132$

Subiza J, Subiza JL, Hinojosa M, Garcia R, Jerez M, Valdivieso R, Subiza $E$ (1989). Anaphylactic reaction after the ingestion of chamomile tea: a study of cross-reactivity with other composite pollens. J. Allergy Clin. Immunol. 84:353-358.

Temme EH, Van Hoydonck PG (2002). Tea consumption and iron status. Eur. J. Clin. Nutr. 56:379-386.

Tôrres AR, Oliveira RAG, Diniz MFFM, Araujo EC (2005). Survey on the use medicinal plants in children hospitalized in the city of João Pessoa city: risks and benefits. Rev. Bras. Farmacogn. 15:7.

Vanaclocha B, Cañigueral S, eds. (2003). Fitoterapia: vademécum de prescripcion, 4 ed. Masson \& Cie, Barcelona.

Wang ZQ, Hamman MA, Huang SM, Lesko LJ, Hall SD (2002). Effect of St John's wort on the pharmacokinetics of fexofenadine. Clin. Pharmacol. Ther. 71:414-420.

Wise LE, Premaratne ID, Gamage TF, Lichtman AH, Hughes LD, Harris LS, Aceto MD (2012). L-theanine attenuates abstinence signs in morphine-dependent rhesus monkeys and elicits anxiolytic-like activity in mice. Pharmacol. Biochem. Behav. 103:245-252.

World Health Organization (WHO) (1999). WHO Monographs on selected medicinal plants - Volume 1. Bulletin of the World Health Organization, Geneva, SW.

World Health Organization (WHO) (2000). General guidelines for methodologies on research and evaluation of traditional medicine. Bulletin of the World Health Organization, Geneva, SW.
World Health Organization (WHO) (2002a). WHO Traditional Medicine Strategy 2002-2005. Bulletin of the World Health Organization, Geneva, SW

World Health Organization (WHO) (2002b). WHO monographs on selected medicinal plants - Volume 2. Bulletin of the World Health Organization, Geneva, SW.

World Health Organization (WHO) (2004a). The World Medicines Situation 2004. Bulletin of the World Health Organization, Geneva, SW.

World Health Organization (WHO) (2004b). WHO Guidelines on safety monitoring of herbal medicines in pharmacovigilance systems. Bulletin of the World Health Organization, Geneva, SW.

World Health Organization (WHO) (2007). WHO monographs on selected medicinal plants - Volume 3. Bulletin of the World Health Organization, Geneva, SW.

World Health Organization (WHO) (2011). The World Medicines Situation 2011- Traditional medicines: global situation, issues and challenges. Bulletin of the World Health Organization, Geneva, SW.

Yoto A, Motoki M, Murao S, Yokogoshi H (2012). Effects of L-theanine or caffeine intake on changes in blood pressure under physical and psychological stresses. J. Physiol. Anthropol. 31:28. 